\title{
The Different Physiological Responses of Natural and Stationary Low Temperature on White Clover (Trifolium repens L.)
}

\author{
Qiu-Jie Yan ${ }^{1,2, a}$, Jin Cai ${ }^{3, b}$, Yan Li ${ }^{2, c}$ and Zhi-Bin Liu* ${ }^{4, d}$ \\ ${ }^{1}$ College of Life Sciences and Technology, Mianyang Normal University, Mianyang 621000, China; \\ ${ }^{2}$ Ecological Security and Protection Key Laboratory of Sichuan Province, Manyang Normal \\ University, Mianyang 621000, China; \\ ${ }^{3}$ West China School of Pharmacy, Sichuan University, Chengdu, Sichuan, 610064, China; \\ ${ }^{4}$ Key Laboratory of Bio-resources and Eco-Environment of Ministry of Education, College of Life \\ Sciences, Sichuan University, Chengdu 610064, China.
}

averonica008@163.com, bshiyan805@126.com,,leeleehi@163.com, 'Izb2003@163.com

\begin{abstract}
Keywords: Trifolium repens L. (Haifa), Natural low temperature, Stationary low temperature,
\end{abstract} Protein content, Membrane lipid peroxidation

\begin{abstract}
Plants initiate lipid peroxidation or accumulate proteins to repair cell membrane damage caused by low temperatures. However, a stationary low temperature simulation cannot accurately explain plant tolerance to naturally low outside temperatures. Our study showed that there was a strong negative correlation between the natural temperature decrease and the protein contents in white clover roots, stems and leaves. The differences between the normal temperature $\left(19^{\circ} \mathrm{C}\right)$ and low temperatures $\left(0{ }^{\circ} \mathrm{C}\right.$ and $\left.5{ }^{\circ} \mathrm{C}\right)$ for lipid peroxidation, chlorophyll content, relative electrolyte leakage, malondialdehyde (MDA) content, and superoxide dismutase (SOD) activity under the stationary low temperature regime were significantly higher than under the natural low temperature regime. While the difference between low temperatures and normal temperatures for relative water content, free proline content, and superoxide anion radical production rates under the stationary low temperature regime did not significantly change compared to the levels recorded under the natural low temperature regime. This finding suggests that the results for low temperature tolerance by white clover under the stationary low temperature by manual simulation regime are different from the natural low temperature regime.
\end{abstract}

\section{Introduction}

Low temperature limits plant distribution on earth. It also decreases the yield and the quality of agricultural products, and even causes plant death [1]. Plants have evolved a variety of efficient mechanisms to cope with low temperature. The most conspicuous changes occur in cellular membranes and to enzymes under low temperature stress conditions [2].

Membrane damage is accompanied by increased leakage of electrolytes and production of reactive oxygen species (ROS). Elevated production of ROS can seriously disrupt cellular homeostasis, which causes damage to lipids, proteins, and nucleic acid [3]. There are non-enzymatic and enzymatic antioxidant mechanisms that eliminate the extra ROS in plants. Furthermore, some osmotic adjustments, such as proline production, may protect cellular membranes against low temperature stress [4].

White clover is extensively used across the globe as a cool season forage legume because it is rich in proteins and very adaptable [5]. Some previous studies have suggested that there is a correlation between increased antioxidant enzyme activity and cold resistance in white clover [6], but these results were observed during short term, low temperature, and manual simulation experiments where rapid temperature changes occurred [7]. Thus, they did not reflect the real mechanisms that white clover uses to resist natural low temperature conditions. Therefore, this study attempted to explore the different properties of white clover under stationary and natural low 
temperature regimes. Especially to what extent stationary low temperature represents the natural low temperatures.

\section{Materials and Methods}

Plant materials and growth conditions. The outdoor white clover at Normal University campus (Mianyang city, Sichuan Province, China) was chosen for the experiment. Mianyang is a subtropical moist monsoon climate with mean annual temperature and mean winter temperature of $18-21^{\circ} \mathrm{C}$ and about $0{ }^{\circ} \mathrm{C}$, respectively. So we choose $19{ }^{\circ} \mathrm{C}$ for normal temperature, $0{ }^{\circ} \mathrm{C}$ and $5{ }^{\circ} \mathrm{C}$ for low temperature. The planted white clover variety was Haifa, Trifolium repens Linn., which was in its second year of growth. Its optimum temperature for growth is $19-25^{\circ} \mathrm{C}$. The sampling area was randomly divided into $9 \mathrm{~m}^{2}(3 \mathrm{~m} \times 3 \mathrm{~m})$ plots, and the samples were collected using the $\mathrm{S}$ shape five-point sampling method. The leaves, stems, roots, flowers, and fruits of the fresh samples were blotted with filter paper and brought to the laboratory so that their physiological indexes could be measured. From September to February of the next year, samples were taken every month between 7:00 am and 9:00 am. The maximum temperature, minimum temperature, and the temperature at the time of sampling were recorded.

Sample preparation before measurement. The protein contents in the different tissues were measured immediately after collection. The membrane lipid peroxidation indexes were measured in the samples collected during October, December, and January. The samples were analyzed over two days. On the first day, whole plant samples with root soil were wrapped in plastic film and placed in a growth chamber. The temperature of the box was adjusted to the low temperatures $\left(0^{\circ} \mathrm{C}\right.$ and $\left.5^{\circ} \mathrm{C}\right)$ for $24 \mathrm{~h}$. Then the samples were removed and measured as the stationary low temperature regime sample. On the second day, a replicate sample was analyzed immediately after collection from the field and these results were taken as the natural low temperature regime sample. All the samples were washed twice with distilled water and then dried with clean filter paper before measurements were taken.

Measurement of relative water content and chlorophyll content in white clover leaves. We measured the plant relative water content (RWC) according to following method. After plant fresh weight (W1) was recorded when collected or prepared, the leaves were left to evaporate under room condition for $2 \mathrm{~h}$ and re-weighed (W2). RWC was calculated by (W1-W2)/W1 $\times 100 \%$. The chlorophyll content was determined in accordance with the following steps. Exactly $0.5 \mathrm{~g}$ fresh leaves were homogenized in $5 \mathrm{~mL}$ of pure acetone, and then centrifuged for 10minutes at 4,000rpm. The total chlorophyll contents were determined in the supernatant by recording the optical density at $664 \mathrm{~nm}, 647 \mathrm{~nm}$, and $625 \mathrm{~nm}$.

Measurement of membrane lipid peroxidation in leaves of white clover. Proline (Pro) content was determined as described following. The $0.5 \mathrm{~g}$ of fresh leaf samples was extracted with $5 \mathrm{~mL} 3 \%$ sulfosalicylic acid, then placed in a boiling water bath for $10 \mathrm{~min}$, and filtered. The extract was added to $6 \mathrm{~mL}$ assay media containing $2 \mathrm{~mL} 2.5 \%$ ninhydrin solution and $2 \mathrm{~mL} 17.5 \mathrm{~mol} \cdot \mathrm{L}-1$ acetic acid, incubated for $30 \mathrm{~min}$ at $100^{\circ} \mathrm{C}$, and then cooled. The coloured product was extracted with $4 \mathrm{~mL}$ toluene with shaking. The absorbance of the resultant organic layer was measured the optical density at $520 \mathrm{~nm}$. Pure proline was used as a standard Malondialdehyde (MDA) content was measured according to the following steps. The $0.5 \mathrm{~g}$ of fresh leaf samples was homogenized with $5 \%$ trichloroacetic acid (TCA) and centrifuged at 4,000 g for $10 \mathrm{~min}$. $2 \mathrm{~mL}$ of extract was added to $2 \mathrm{~mL} 0.6 \%$ thiobarbituric acid (TBA) placed in a boiling water bath for $10 \mathrm{~min}$, and the absorbance at 532, 600, and 450nm was determined the optical density. The relative electrolyte leakage(REL) was measured according to the following method. $10 \mathrm{~mL}$ distilled water were added to infiltrate every sample in vacuum. After digested for $3 \mathrm{~h}$ at $25 \mathrm{oC}$, the conductivity(E1) of the samples were measured. And then, the samples were boiled for $10 \mathrm{~min}$, and cooled to $25 \mathrm{oC}$, added distilled water up to $10 \mathrm{~mL}$, again measured the conductivity(E2). the relative electric conductivity of each sample is calculated by E1/E2×100\%.

Measurement of protein content and SOD activity. The activity of superoxide dismutase 
(SOD) was assayed in accordance with the following steps. The $0.5 \mathrm{~g}$ fresh white clover leaves were grinded with pre-chilled mortar and pestle at $0^{\circ} \mathrm{C}$ and total proteins were extracted with 0.05 $\mathrm{mol} \cdot \mathrm{L}^{-1} \mathrm{pH} 7.0$ ice-cold phosphate buffer $\left(1 \mathrm{mmol} \cdot \mathrm{L}^{-1}\right.$ EDTA, pH7.8, $0.1 \%$ TritonX-100, $1 \mathrm{mmol} \cdot \mathrm{L}^{-1}$ PMSF, 2\%PVP). Homogenate was centrifuged with 4,000 rpm for $20 \mathrm{~min}$ at $4^{\circ} \mathrm{C}$. The obtained supernatant was the crude enzyme extract used for parallel tests of protein quantity and enzyme activity. Protein content of samples was measured using Coomassie brilliant blue G250 dye-binding assay with bovine serum albumin as a standard. When SOD activity was determined, adding enzyme and reaction for $10 \mathrm{~min}$, then rapid determination of the optical density under $560 \mathrm{~nm}$, the phosphate buffer without the enzyme solution as control.

Measurement of superoxide anion free radical production rate in leaves of white clover. To measure the superoxide anion free radical production rate, the $5 \mathrm{~g}$ fresh leaves were grinded with $6 \mathrm{~mL} 65 \mathrm{mmol} \cdot \mathrm{L}^{-1} \mathrm{pH} 7.8$ phosphate buffer, and then filtered by four layers of gauze. The filtrate was

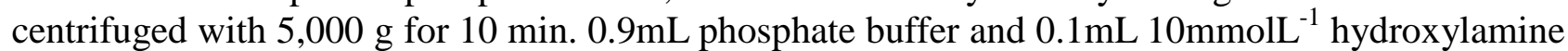
chloride were put into $1 \mathrm{~mL}$ supernatant, mixed at $25^{\circ} \mathrm{C}$ and cultured it for $20 \mathrm{~min}$. Added $0.5 \mathrm{~mL}$ $17 \mathrm{mmol} \cdot \mathrm{L}^{-1}$ sulfanilic acid and $0.5 \mathrm{~mL} 7 \mathrm{mmol} \cdot \mathrm{L}^{-1} \alpha$-naphthylamine into $0.5 \mathrm{~mL}$ culture solution, let it reaction for $20 \mathrm{~min}$ at $25^{\circ} \mathrm{C}$. The mixed color liquid after reaction was fully shaken with the same volume of n-butanol. The solution was stand until it becoming two layers of liquids. And the n-butyl alcohol phase was taken and determined the optical density of 530nm, the phosphate buffer as control.

Statistical analysis. Data are presented as the mean \pm standard deviation of three replicates. The correlation analysis and the significant of correlation coefficient were tested using pearson correlation of SPSS11.5 software, levels of significance are $P<0.01$ or $P<0.05$.

\section{RESULTS}

Changes to the Protein Content in the Different Tissues over the Growing Season. The air temperature gradually decreased from $20^{\circ} \mathrm{C}$ of September to $0^{\circ} \mathrm{C}$ of January, and then increased from January (Fig. 1A). In contrast, the protein content of the leaves, stems, and roots gradually increased from October, reaching a peak in January, and fell back from January onwards (Fig. 1B). Especially the protein content of the leaves, it increased from $33.27 \mu \mathrm{g} \cdot \mathrm{g}^{-1} \cdot \mathrm{FW}^{-1}$ in September to $166.13 \mu \mathrm{g} \cdot \mathrm{g}^{-1} \cdot \mathrm{FW}^{-1}$ in January, and dropped to $151.79 \mu \mathrm{g} \cdot \mathrm{g}^{-1} \cdot \mathrm{FW}^{-1}$ in February. There were very significant differences in protein content between November, December, January, and February, compared to September $(P<0.01)$. The correlation analysis showed that there was a very significant negative correlation between protein content and temperature $(P<0.01)$ (Fig. 1C). The correlation coefficients were $-0.9500,-0.9737$ and -0.9897 for the leaves, stems and roots, respectively. The protein content of white clover reproductive organs remained virtually the same from September to November (Fig. 1D). However, the protein content in the fruit was higher than in the flowers. The changes range of the protein content in flowers and fruits is between $16.44-19.33 \mu \mathrm{g}^{-1} \cdot \mathrm{FW}^{-1}$. Furthermore, the flower and fruit protein content gradually dropped from October to November, whereas there was little change in the protein contents in the flowers and fruits in the period before they began to fall $(P>0.05)$. 

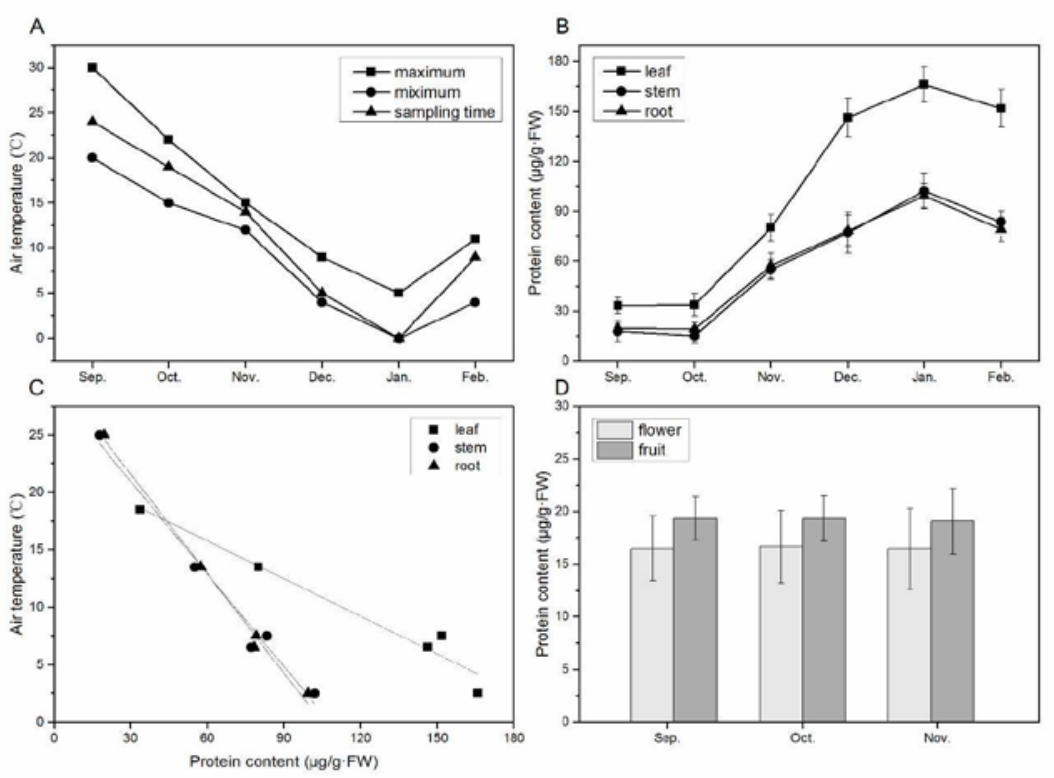

Fig.1 The protein contents in the leaves, stems, and roots of white clover were negatively related to the change in temperature.

A. The maximum, minimum, and sampling time temperatures between September and February of the next year. B. The protein contents of leaves, stems, and roots of white clover under the natural temperature regime. C. Correlation analysis between the protein contents of the leaves, stems, and roots, and the temperature. D. The protein contents of white clover flowers and fruit between September and November.

Changes in the Relative Water Content and Chlorophyll Content of White Clover Leaves under the Natural and Stationary Low Temperature Regimes. The relative water content and chlorophyll content of white clover leaves fell from 95.4 to $80.8 \%$ and from 1.849 to $1.394 \mathrm{mg} \cdot \mathrm{g}^{-1}$, respectively, as the temperature dropped (Fig. 2). There were no significant differences in the relative water content of the leaves between $5^{\circ} \mathrm{C}$ and $0^{\circ} \mathrm{C}$, and the normal temperature under the natural low temperature and the stationary low temperature regimes (Fig. 2A). However the chlorophyll content of the leaves was significantly different at $0^{\circ} \mathrm{C}$ compared to $19^{\circ} \mathrm{C}$ under the stationary low temperature regime, but there was no significant difference under the natural low temperature regime (Fig. 2B). Therefore the stationary low temperature regime at $0^{\circ} \mathrm{C}$ produced different results for chlorophyll content than the natural temperature regime at $0^{\circ} \mathrm{C}$.
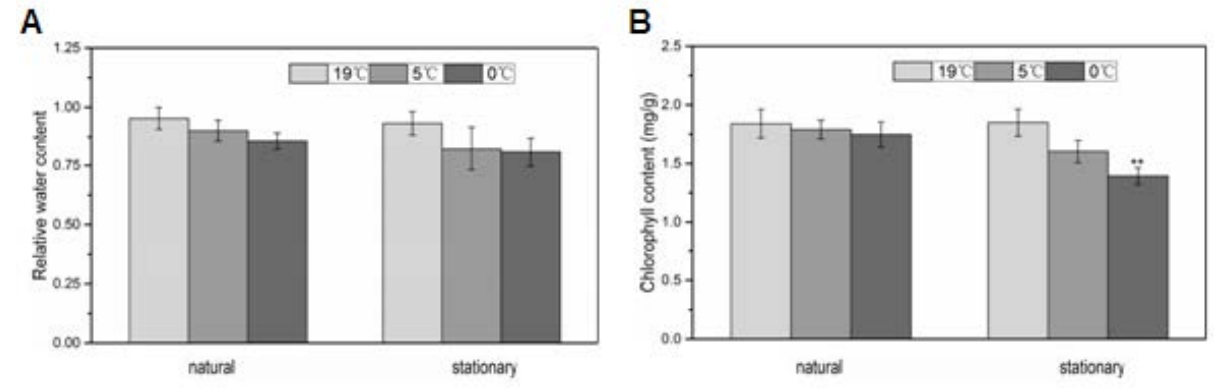

Fig. 2 The relative water content(A) and the chlorophyll content(B) of white clover leaves at $5{ }^{\circ} \mathrm{C}$ or

$0{ }^{\circ} \mathrm{C}$ Membrane Lipid Peroxidation of White Clover Leaves under the Natural and Stationary

Low Temperature Regimes. The relative electrolyte leakage, the MDA content, and the free Proline contents of white clover leaves all increased from $15.18 \%$ to $26.54 \%$, 3.68 to $8.51 \mu \mathrm{mol} \cdot \mathrm{g}^{-1}$ and 18.26 to $45.62 \mu \mathrm{g} \cdot \mathrm{g}^{-1} \cdot \mathrm{FW}^{-1}$, respectively, as the temperature fell (Fig.3). There were very significant differences between the relative electrolyte leakage values at $19^{\circ} \mathrm{C}$ under the stationary low temperature regime and the values at $5^{\circ} \mathrm{C}$ or $0^{\circ} \mathrm{C}$ (Fig. 3A). However, the differences between 
the $5^{\circ} \mathrm{C}$ and $0^{\circ} \mathrm{C}$ values under the stationary low temperature regime were not significantly different. The MDA contents at $0^{\circ} \mathrm{C}$ were very significantly different from the values at $19^{\circ} \mathrm{C}$ for both the natural and the stationary low temperature regimes, but the MDA contents at $5^{\circ} \mathrm{C}$ were only significantly different from the value at $19^{\circ} \mathrm{C}$ under the stationary low temperature regime (Fig. 3B). The values for free Pro content at $0^{\circ} \mathrm{C}$ were significantly different from the values at $19^{\circ} \mathrm{C}$ for both the natural and the stationary low temperature regimes (Fig. 3C). Membrane lipid peroxidation in white clover leaves under the natural temperature regime was significantly different from the stationary low temperature regime. The stationary low temperature relative electrolyte leakage and the MDA results at $5^{\circ} \mathrm{C}$ were significantly different than the natural temperature results at $5^{\circ} \mathrm{C}$. The stationary low temperature relative electrolyte leakage results were also significantly different from the natural temperature results at $0^{\circ} \mathrm{C}$.
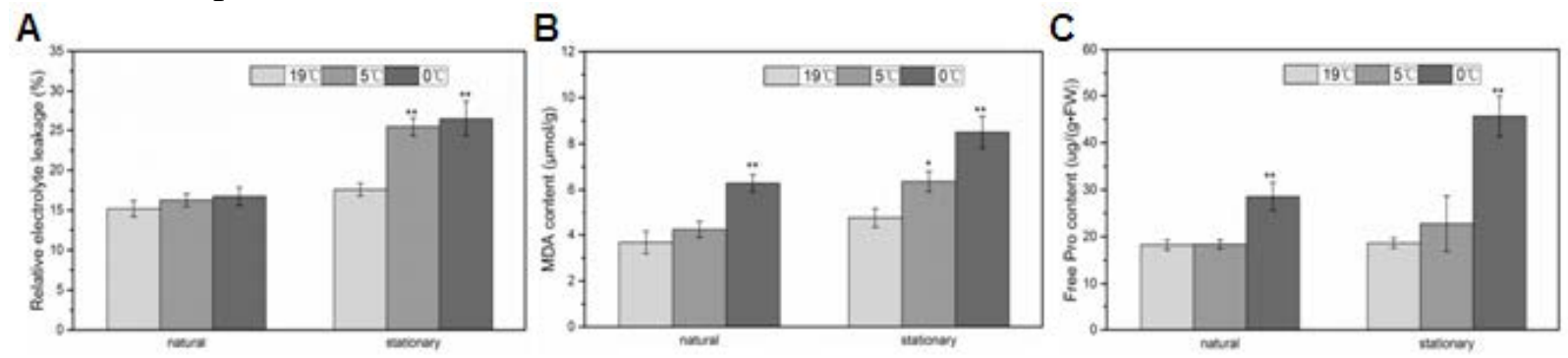

Fig. 3 The relative electrolyte leakage(A), the MDA content(B), and the free Pro content(C) of white clover leaves at $5{ }^{\circ} \mathrm{C}$ or $0{ }^{\circ} \mathrm{C}$.

Changes in SOD Activity and the Superoxide Anion Radical Production Rate in White Clover Leaves under the Natural and Stationary Low Temperature Regimes. The SOD activity and the superoxide anion radical production rate in white clover leaves under the natural and stationary low temperature regimes both increased as the temperature fell (Fig. 4). The ranges is between 100.81 and $201.53 \mathrm{U} \cdot \mathrm{mg}^{-1}$ for SOD activity, and between 0.457 and $18.427 \mathrm{U} \cdot \mathrm{mg}^{-1}$ for the superoxide anion radical production rate. The SOD enzyme was more active under the stationary low temperature regime than under the natural low temperature regime (Fig. 4A). There were significant differences between stationary low temperature activities at $5^{\circ} \mathrm{C}$ or $0^{\circ} \mathrm{C}$, and the values at $19^{\circ} \mathrm{C}$ (Fig. 4B). However there were no differences in activities under the natural low temperature regime. The changes in the superoxide anion radical production rate were very significantly different between $5^{\circ} \mathrm{C}$ or $0^{\circ} \mathrm{C}$, and $19^{\circ} \mathrm{C}$ for both the natural and stationary low temperature regimes. However, the superoxide anion radical production rate under the stationary low temperature regime was 2 times greater than under the natural low temperature regime. The stationary low temperature regime at $5^{\circ} \mathrm{C}$ and $0^{\circ} \mathrm{C}$ produced significantly different SOD activity results from the natural temperature regime at $5^{\circ} \mathrm{C}$ and $0^{\circ} \mathrm{C}$.

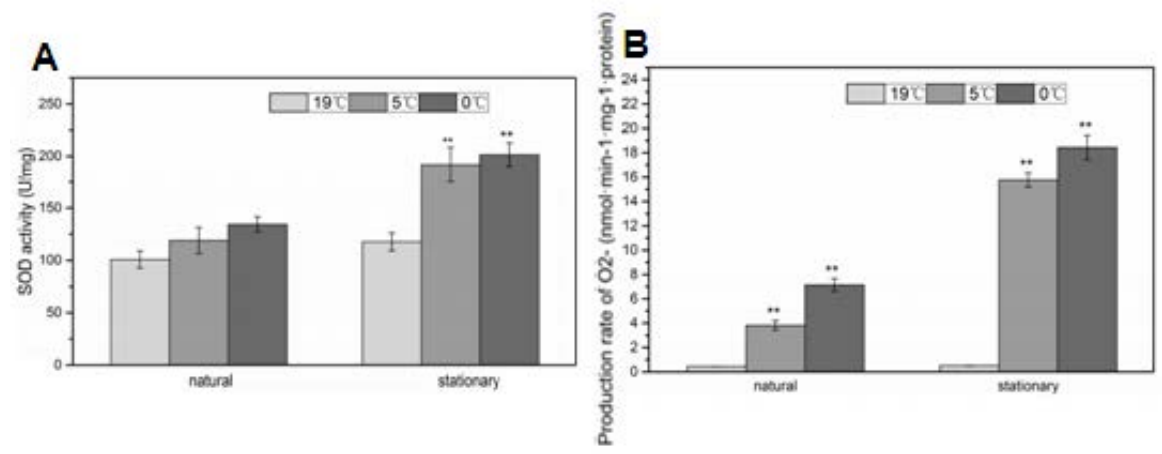

Fig. 4 The SOD activity(A) and the superoxide anion radical production rate(B) in white clover leaves at $5{ }^{\circ} \mathrm{C}$ or $0{ }^{\circ} \mathrm{C}$.

\section{Discussion}

There has been considerable previous research into the mechanisms underlying plant tolerance to low temperatures [8]. Arabidopsis is capable of cold acclimation, i.e., during a period of cold, 
non-freezing temperatures, its tolerance of freezing temperatures increases [9]. This process, also referred to as cold hardening, involves many metabolic and developmental changes, which lead to the accumulation of proteins and compatible solutes, and alterations in membrane composition [10]. Our study showed that protein content increased at low temperatures (Fig. 1A, Fig. 1B), and that there was a significant negative correlation between the decrease in temperature and increased protein content (Fig. 1C). This indicated that low temperature initiated the expression of cold induced proteins and a rapid increase in protein content. Although protein accumulated at low temperatures, there were differences in protein content between the different white clover tissues. In this study, it was noticed that the protein contents in the flowers and fruit of the white clover did not increase as the temperature fell (Fig. 1D), whereas they did in the leaves, stems, and roots. This may be due to the fact that flowers and fruits only exist for a relatively short period of time. Although the natural temperatures fell between September and October, the temperatures were still relatively high during this period, at above $15^{\circ} \mathrm{C}$, which is a suitable growth temperature for white clover. So the protein contents in the leaves, stems, and roots remained substantially unchanged during this period.

Low temperatures first alter the membrane phase of the phospholipid bilayer. The change in the membrane phase may inhibit cell membrane function, and the change in configuration may influence membrane stability [11]. If the cell membrane ruptures, then the macromolecule substances in the cells would exosmose. This could lead to the formation of ice in the intercellular space and to a decrease in the osmotic pressure differential, which would increase cellular dehydration. Cell membrane penetrability was evaluated by the relative conductance of the cell membrane under cold stress [12]. In this study, as the temperature fell, the relative water and chlorophyll contents in the white clover leaf cells both decreased (Fig. 2), which suggested that low temperature stress damaged the plant cell membrane, and affected plant photosynthesis. However, relative electrolyte leakage did not exceed $50 \%$ (Fig. 3A), which indicated that low temperatures did not destroy the white clover leaf cell membrane system. Membrane damage can also be evaluated by MDA production, which is considered to be the final product of lipid peroxidation in the plant cell membrane [13]. In our experiment, the increase in the MDA content indicated that low temperature stress caused some damage to the cell membrane and induced a rapid increase in MDA (Fig. 3B). The free proline acts as an osmolyte to facilitate osmoregulation, which protects plants from dehydration caused by cold stress by reducing plant cell water potential [14]. Our study indicated that low temperatures led to the accumulation of free proline in the leaves of white clover (Fig. 3C), and this was consistent with previous studies [15].

The production and metabolism of active oxygen in vivo is at equilibrium under normal circumstances, but this balance is disrupted at low temperatures. Large amounts of active oxygen and excess free radicals accumulate in vivo [16]. The function of SOD is to remove the $\mathrm{H}_{2} \mathrm{O}_{2}$ produced during oxygen metabolism and some of the free radicals produced from it. In this study, the increase in SOD activity, combined with superoxide anion radical accumulation (Fig. 4), strongly indicated that low temperature stress disrupted the active oxygen metabolism balance in vivo, which led to the accumulation of active oxygen.

In summary, the $5^{\circ} \mathrm{C}$ or $0^{\circ} \mathrm{C}$ low temperatures increase membrane lipid oxidation and gradually initiate the resistance system, which enhances protein expression levels, but do not destroy the cell membrane system. This indicates that the white clover is resistant to continuously low temperatures after the initial temperature decrease. Therefore, moderate acclimation under the natural low temperature regime can increase the expression of low temperature induced proteins. We found that there is considerable variability between the changes that occur in the plant under the natural low temperature and stationary low temperature regimes, which indicated that plant low temperature stress caused by the stationary low temperature regime was greater than the stress caused by the natural low temperature regime.

\section{Acknowledgments}

This project was funded by National Natural Science Foundation of China No. 31300996, the program 2015NZ0036(supported by Science and Technology Department of Sichuan province)and 
the Youth Fund MA2010006 (supported by Mianyang Normal University).

* Author to whom correspondence should be addressed; Tel.: +86-28-8541-2281.

\section{References}

[1] Bressan R., Bohnert H., Zhu J.K., Abiotic stress tolerance: from gene discovery in model organisms to crop improvement, Molecular Plant. 2(2009) 1-2.

[2] Lukatkin, A.S. Contribution of oxidative stress to the development of cold-induced damage to leaves of chilling-sensitive plants: 3. Injury of cell membranes by chilling temperatures, Russian Journal of Plant Physiology. 50(2003) 243-246.

[3] Charles J.B., Henning R., Nicolas S., Dirk R., Kiran R.P., Jens N., Joachim S., Liu J., Alisdair R.F., Lee J.S ., The metabolic response of heterotrophic Arabidopsis cells to oxidative stress, Plant Physiol. 143(2007) 312-325.

[4] Zhang J., Jiang F.W., Yang P., Li J., Yan G.J., Hu L.Y., Responses of canola (Brassica napus L.) cultivars under contrasting temperature regimes during early seedling growth stage as revealed by multiple physiological criteria, Acta Physiologiae Plantarum. 37(2015) 6-15.

[5] Zhang Y., He J., Zhao P.X., Bouton J.H., Monteros M.J., Genome-wide identification of microsatellites in white clover (Trifolium repens L.) using FIASCO and phpSSRMiner, Plant Methods. 4(2008) 19.

[6] Dalmannsdóttir S., Aslaug H.Á., Gudleifsson B.E. Fatty acid and sugar content in white clover in relation to frost tolerance and ice-encasement tolerance, Annals of Botany. 88(2001) 753-759.

[7] Zhao M., Zhou R.L., Liu J.F., Zhong X.SH., The relationship between freeze-tolerance and changes in activities of antioxidant enzymes and osmolyte content in the leaves of white clover during early winter frezze-thaw cycles, Acta Ecologica Sinica. 31(2011) 306-315.

[8] Arisz S.A., Van W.R., Roels W., Zhu J.K., Haring M.A., Munnik T., Rapid phosphatidic acid accumulation in response to low temperature stress in Arabidopsis is generated through diacylglycerol kinase, Front Plant Sci. 4(2013) 1-15.

[9] Heather A., Van B., Michael F.T., Arabidopsis transcription factors regulating cold acclimation, Physiologia Plantarum. 126(2006) 72-80.

[10] Cook D., Fowler S., Fiehn O., Thomashow M.F., A prominent role for the CBF cold response pathway in configuring the low-temperature metabolome of Arabidopsis, Proceedings of the National Academy of Sciences of the United States of America. 101(2004) 15243-15248.

[11] Steponkus P.L., Uemura M., Webb M.S. Advances in Low-temperature Biology, JAI Press, London, 1996.

[12] Rohde P., Hincha D.K., Heyer A.G. Heterosis in the freezing tolerance of crosses between two Arabidopsis thaliana accessions (Columbia-0 and C24) that show differences in non-acclimated and acclimated freezing tolerance, Plant Journal, 38(2004) 790-799.

[13] Hodges D.M., DeLong J.M., Forney C.F., Prange R.K., Improving the thiobarbituric acid-reactive-substances assay for estimating lipid peroxidation in plant tissues containing anthocyanin and other interfering compounds, Planta. 207(1999) 604-611.

[14] Székely G., Ábrahám E., Cséplő A., Rigó G., Zsigmond L., Csiszár J., Ayaydin F., Strizhov N., Jásik J., Schmelzer E., Koncz, C., Szabados, L., Duplicated P5CS genes of arabidopsis play distinct roles in stress regulation and developmental control of proline biosynthesis, Plant Journal. 53(2008) 11-28. 
[15] Liu W.Y., Wang M.M., Huang J., Tang H.J., Lan H.X., Zhang H.S., The OsDHODH1 gene is involved in salt and drought tolerance in rice, Journal of Integrative Plant Biology. 51(2009) 825-833.

[16] Du J.B., Yuan S.H., Chen Y.E., Sun X., Zhang ZH.W., Xu F., Yuan M., Shang J., Lin H.H., Comparative expression analysis of dehydrins between two barley varieties, wild barley and Tibetan hulless barley associated with different stress resistance, Acta Physiologiae Plantarum. 33(2011) 567-574. 